\title{
A VALSA DO LEVIATÃ PÓS-MODERNO: VELHOS CISNES ÔNTICOS SOBRE NOVOS LAGOS EPISTÊMICOS
}

\author{
THE POST-MODERN LEVIATHAN WALTZ: \\ OLD ONTIC SWANS ABOUT NEW EPISTEMIC LAKES
}

\author{
Denise Bermudez de Oliveira Moraes* \\ Ricardo Aronne**
}

RESUMO: Este breve ensaio trata do Estado moderno e de sua influência no sistema jurídico. Por meio das figuras da Valsa e do Ballet, percorrem-se as lacunas decorrentes da incidência do tempo sobre os fundamentos do Estado, revelando a complexidade do sistema jurídico na Pós-Modernidade.

PALAVRAS-CHAVE: Estado. Pós-Modernidade. Historicismo. Sistema Jurídico. Complexidade.

ABSTRACT: This brief rehearsal deals with the modern State and its influence in the legal system. Through Waltz and Ballet, it runs through gaps of the incidence of the time about the foundation of the State. Revealing the complexity of the juridical system in the post-modernity time.

KEYWORDS: State. Post-modernity. Historicity. Legal System. Complexity.

* Mestranda em Direito pela Pontifícia Universidade Católica do Rio Grande do Sul - PUCRS, PósGraduanda em Direito Tributário pela Fundação Getúlio Vargas, Procuradora da Fazenda Nacional e Pesquisadora do Grupo de Pesquisa Prismas do Direito Civil-Constitucional (PUCRS/CNPq).

**Pós-Doutor em Direito Privado pela UFPR, Doutor em Direito Civil e Sociedade pela UFPR, Mestre em Direito do Estado pela PUCRS, Especialista em Direito Processual pela PUCRS, Professor Titular dos Programas de Graduação, Mestrado e Doutorado da PUCRS, Professor Convidado dos programas de PósGraduação da UFS, UFPI e UNIT, Advogado e Pesquisador Líder do Grupo de Pesquisa Prismas do Direito Civil-Constitucional (PUCRS/CNPq). E-mail: ricardo.arone@gmail.com 
Retomar o Estado, como tema para um ensaio jurídico, não interessa apenas em apanhar um tema entre tantos, como uma flor de primavera pinçada em ramalhete por dedos apaixonados dentre outras que se lhe irmanam na mirada floreira de um certo canteiro.

Não obstante ser como aquela flor, cuja possibilidade de estar no jardim ou na praça (SALDANHA, 1986) lhe permita se insinuar do Público ao Privado ${ }^{1}$, possui uma singularidade inata derivada de sua historicidade ${ }^{2}$ e da alteridade que se lhe entranhou. Mutável e dotado de um ânima qual os tigres de Borges. O Estado não é mais um tema entre outros.

É um tema que se retoma constantemente, como imanência de um direito moderno e racionalmente jurisdicionado, que consegue se disfarçar de obviedade por tão grande presença, a ponto de ganhar certas invisibilidades temáticas que, sem o recurso da desconstrução, facilmente fogem aos sentidos.

Leviatã, sem dúvida importou em uma designação feliz por Hobbes ${ }^{3}$, em diversos aspectos. Dentre esses, para além do poder, temor, mítica ou sobrenaturalidade, a organicidade e adaptatividade decorrente de sua condição de um ente de alma política e carne burocrática, parace guardar uma importância irrefutável ao Direito, seja nas luzes do palco público, seja nas sombras das arenas privadas.

Essas linhas se propõem a invadir esses territórios epistêmicos, ainda colonizados por uma ontologia sem cidadania na contemporaneidade da vida e sedenta por se afirmar, em um mundo que lhe foge cotidianamente.

Busca, assim, demarcar qual o sentido das proposições originárias do Estado Moderno, não obstante repetidas e reafirmadas em discursos embalsamados e categoriais ${ }^{4}$,

1 Saldanha (1986) utiliza o jardim e a praça como metáforas centrais, representando, respectivamente, o espaço privado e o público. Com esse paralelo desvela relações, contradições, continuidades e descontinuidades, tal como ocorrem na vida histórica. Entre um espaço e outro, sobressai a imagem do homem construída pelo próprio homem, bem como as crises decorrentes da articulação entre a vida pública e privada que se prolongam na contemporaneidade.

2 De acordo com Sztompka (1998, p.14-15): “Uma das peças mais preciosas do saber sociológico é o princípio do historicismo. Ele diz que para compreender qualquer fenômeno contemporâneo devemos pesquisar suas origens e processo de formação. O mesmo se aplica ao reino das idéias; é impossível compreender visões contemporâneas da mudança social sem identificar quais concepções anteriores elas pretendem aperfeiçoar e a quais teorias se contrapõem."

3 Para Hobbes (2005), o Estado, ser artificial que se move tal qual um relógio, é materializado pelo medo produzido pelo outro, pela necessidade de conter a natureza humana em prol da conformação social. Mediante uma matematização da sociedade, geometricamente calculada, emerge um Estado forte e um indivíduo frágil como solução racional à civilização.

4 Discursos que traduzem um modelo de racionalidade que reduz a complexidade do real, que transforma o 'conhecer' em simples divisão e classificação. 
que ainda se mantêm ontologicamente infensas aos assaltos da contemporaneidade que lhe assombra e se lhe assoma ${ }^{5}$.

\section{UM ESTADO PARA O MERCADO.}

Quando, ao início do Século das Luzes ${ }^{6}$, as valsas começavam a embalar os passos das elites europeias, através dos salões de palácios que já haviam conhecido diversos projetos de poder ao longo da história, um novo Leviatã - ainda não claramente delineado - era uma indisfarçável presença entre quaisquer convivas.

Da mesma forma que a nova valsa se distanciava das danças camponesas de onde provinha, os passos desse Leviatã Moderno, renascido qual Fênix das cinzas das revoluções liberais (inglesa, americana e, por fim, a francesa), seriam irreconhecíveis ao populacho ainda em busca dos sugeridos brioches para seu sustento.

Buscava concretizar o ideal iluminista de um Estado racional ${ }^{7}$, no simplificado horizonte do laissez faire justificador do minimalismo estatal característico do liberalismo clássico. ${ }^{8}$

5 Para Bauman (1999, p. 18): “A modernidade é o que é - uma obsessiva marcha adiante - não porque sempre queira mais, mas porque nunca consegue o bastante; não porque se torne mais ambiciosa e aventureira, mas porque suas aventuras são mais amargas e suas ambições frustadas. A marcha deve seguir adiante porque qualquer ponto de chegada não passa de uma estação temporária. Nenhum lugar é privilegiado, nenhum melhor do que outro, como também a partir de nenhum lugar o horizonte é mais próximo do que de qualquer outro. É por isso que a agitação e a perturbação são vividas como uma marcha em frente; é por isso, com efeito, que o movimento browniano parece adquirir verso e reverso e a inquietude uma direção: trata-se de resíduos de combustíveis queimados e fuligem de chamas extintas que marcam as trajetórias do progresso."

6 Segundo Edgar Morin (2005, p. 37): "O espírito humanista das Luzes encontrará a sua formulação na Declaração dos Direitos do Homem e do Cidadão, sendo esta mensagem muito mais suportada pela aristocracia iluminada do que pela burguesia, como demonstrou François Furet. Durante a noite do 4 de Agosto, os aristocratas, por sua iniciativa, abandonaram os seus privilégios. No entanto, a razão, durante esta época que marca o seu triunfo, arvora diferentes faces. A razão científica constrói teorias. Mas estas teorias, aparentemente fundamentadas em dados coerentes, podem ser manchadas pela 'racionalização', por uma visão demasiado lógica que apenas retém o que a confirma."

7 De acordo com Barzotto (1999, p. 138): “O homem moderno lança-se à construção de um mundo calculável, previsível, certo. O desafio era construir uma ordem que garantisse as expectativas dos indivíduos em uma sociedade que, liberta dos laços feudais, tinha-se tornado uma sociedade de estranhos, sem um ethos comum e submetidos a um poder que, ao colocar acima da sociedade, representava um risco constante. Nesse novo mundo, o direito positivo torna-se o principal meio de integração social e a única garantia do indivíduo contra o poder estatal. Mas isso faz com que a segurança na vida social passe a depender, de modo dramático, da exata determinação do jurídico. Essa é a missão histórica que o liberalismo confiou ao positivismo: garantir a segurança nas relações sociais por meio de um conceito de direito perfeitamente delimitado em relação à moral e à política, resguardando o direito das ameaças representadas pelo pluralismo axiológico e pelo arbítrio estatal."

8 Para Ricardo Aronne (2001, p. 227): “Com o fim do absolutismo, na Revolução Francesa, advindo o Estado Liberal Clássico, erigindo-se, para tanto, um sistema jurídico que toma por princípio estruturante o princípio da liberdade, irrelativizável, justificando inclusive um corte drástico entre o público e o privado, de modo a não se admitir a intervenção do público nas relações interprivadas, o tratamento absoluto dos vínculos reais mantém serventia, por resguardar o patrimônio da burguesia dos arbítrios do Estado, os quais motivaram a Revolução." 
$\mathrm{Na}$ ratio dessas escolhas estava a salvaguarda a joia suprema da paradigmática coroa moderna, representativa desse capital espaço da vida e verdadeiro berço da moral burguesa. Lá estava o Mercado, cujos tentáculos tomariam a forma dos braços que conduziriam a valsa do Leviatã. E ao início dos passos da magnífica dança, os giros e rodopios dos bailantes, por mais definidos que esses sejam, não mais nos permitem circunscrever com clareza os espaços do que ora é Público e ora é Privado.

O Estado, em tese um privilegiado espaço representativo da esfera do Público, é instrumentalizado e alimentado por uma percepção contratualista que encarna os mais representativos espaços da esfera do Privado.

O Estado Moderno nasce para garantir, resguardar e implementar o Mercado. É no Mercado que a cidadania moderna se legitima e justifica. Retrato da vida burguesa, estampada nos quatro personagens da biografia estampada na codificação, então afirmada Constituição do Homem Privado, o marido, contratante, proprietário e testador, para o indivíduo "ser" era preciso antes "ter". 9 "

O Direito Civil nasce para regular os três pilares da vida privada (o contrato, a família e, em especial, a propriedade privada), tal qual o Direito Penal Moderno nasce para dar margens (marginalizar) àqueles que optem por arranhar tais bastiões eleitos por elites de novas sociedades, ainda caricatamente hiperbólicas em seus credos de fundo (Pátria, Deus, Família, Bandeira, Hino,...).

Atrás da cena, como a espiar na cochia os espirais dos bailarinos coadjuvantes, o Leviatã trajado de cisne jamais adentra o palco na ausência de sua deixa. Roteirizado pela legalidade clássica, o rei tornara-se um hipertrofiado peão no tabuleiro econômico e político da Modernidade Sólida.

Esse Estado Gendarme é imóvel na esfera privada em face da legalidade estrita. O Liberalismo Clássico deixa o antigo continente imerso em um amplo campo da autonomia privada, onde o voluntarismo derivado do fetiche da autonomia de vontade importa em um dique econômico, provedor da acumulação de renda. ${ }^{10}$

Pela ausência do Público na esfera Privada, onde uma igualdade formal pressupõe uma isonomia no campo social e econômico que inexiste e fica ainda mais distante em face dos paradigmas iluministas, que lançam trevas no Século das Luzes.

O Trabalho, por exemplo, solto no campo do privado e apropriado pelo Contrato então colonizado pela Teoria da Vontade, é um espaço fácil de radiografar. Única

9 “Os códigos civis tiveram como paradigma o cidadão dotado de patrimônio, vale dizer, o burguês livre do controle ou impedimento públicos. Nesse sentido é que entenderam o homem comum, deixando a grande maioria fora de seu 'alcance'. Para os iluministas, a plenitude da pessoa dava-se com o domínio sobre as coisas, com o ser proprietário." (LÔBO, 1999, p. 101).

${ }^{10}$ Para Ricardo Aronne (2010, p.112): “ Esse Estado Gendarme tem um compromisso por excelência: deixar tudo como está. Garantir o status quo. Agora, o cidadão, despojado da condição vassalar que lhe agrilhoava qual servo, é o Senhor. A saúde da nação sera garantida pela Lei do Mercado, oferta e procura assegurada pela condição negativa do Estado, conforme a fórmula revelada por Adam Smith. Lex Mercatoria.” 
mercadoria dos economicamente vulneráveis, outrora campesinos ora proletários, a força de trabalho é o bem que lhes é possível de ser posto no Mercado. Este último, regido pela lei da demanda, projeta os salários para um deficitário patamar pelo inundar da oferta em razão das vagas de trabalho, gestando um chamado Exército do Operariado de Reserva.

Assim, quem ofertava as vagas ditava os preços de modo a visibilizar a impossibilidade de autonomia de vontade como concebido ao civilismo tradicional, que somente imaginava uma intervenção contratual para sua dissuasão e tão somente diante de um vício de vontade (fosse erro, dolo, ou coação).

Pensar o contrário importaria no desenjaular do Leviatã, promovendo-lhe a potência invasiva dos idos do ancient regim. O Público era pensado e projetado pelo e para o Privado. E os direitos fundamentais, de recente invenção e eficácia unicamente vertical, serviam de instrumento para murar o cidadão contra o Estado.

Montesquieu (1995) castrara o Leviatã, mediante sua tripartite cirurgia política, e a Escola da Exegese castrara os juristas, com o auge das codificações no cenário do Direito.

Castrara pelas especialidades, modernamente cartesianas, tal qual a especialização moderna castrou o pensamento humano, em diversos dos seus horizontes. A partir da Escola e da Indústria, postara-se em todos os campos e cenários. A própria classe política, retrato da especialização das atividades, nascera no Velho e no Novo Mundo. Antes se fazia política, agora se era político. ${ }^{11}$

República, muito antes de ser um espaço democrático, era concebida como um espaço de desmedida liberdade de Mercado e da vida civil. Um fetiche meritocrático desenvolvimentista perpassa todos os valores dessa segregante e darwinista sociedade burguesa, recorporificadora das noções de culpa e responsabilidade, outrora religiosas, agora político-jurídico-econômico-sociais desse universo do Deus Metal. ${ }^{12}$

O Estado existia para salvaguarda do Contrato e da Propriedade. ${ }^{13}$ Era administrado para a parcela proprietária, detentora do poder eletivo e destinatária da

11 Conforme Ricardo Aronne (2012, p.77): "Essa modernidade cartesiana, individualista e privatista, introdutora da especialidade e da especialização (resultante no fordismo) em todos os aspectos do quotidiano, vê na política mais um aspecto dessa mesma especialização, passando a gerar e gerir uma respectiva classe política em seus intestinos sociais."

12 Eugênio Fachini Neto (2010, p.44) esclarece: “As normas estatais protetoras do indivíduo buscavam assegurar tão somente seu espaço de liberdade econômica, protegendo o cidadão contra o próprio Estado. As limitações aos direitos subjetivos, quando existentes, eram apenas aquelas necessárias para permitir a convivência social. Nítida, aqui, a inspiração kantiana: minha liberdade irrestrita só encontra limitações na idêntica liberdade de meu semelhante."

${ }^{13}$ Segue o autor: "No mundo jurídico, tudo isso desemboca na ética do individualismo, com o aprimoramento, pela pandectística, das figuras do sujeito de direito (enquanto sujeito abstrato) e do direito subjetivo. Os códigos civis deste período caracterizam-se por estarem centrados na propriedade, com ênfase na propriedade imobiliária, com caráter absoluto e individualista, no voluntarismo jurídico, na liberdade e autonomia contratual, na igualdade meramente formal." (FACHINI NETO, 2010, p. 45). 
tutela juridicional civil... Para suas margens ficava a fúria punitiva-educativa do Poder Público, ao pronto serviço do Poder Privado.

A felicidade econômica implicava um progressivo descarte social anexo às mais diversas medidas de produtividade do sujeito/sujeitado com vistas à emergência.

E o Leviatã cruzava o lago nas vestes do Cisne Branco, traçando os passos do Cisne Negro. Quem é Leviatã? Qual cisne atravessa o lago?

\section{A "DESCASTRAÇÃO" DO LEVIATÃ.}

O lento despertar do Leviatã, impulsionado pelos marcantes movimentos nas ruas da Paris do Século XIX e os levantes das comunas (LISSAGARAY, 1991), tal qual se viu nos levantes da massa suburbana no recente 2007, foi progressivo e viral no ocidente judaico-cristão. A cena das ruas em chamas da Cité Lumiére oitocentista é representativa da pressão social que sacudia o caldeirão liberal europeu da época.

Aos que resistiram às pressões, mantendo-se surdos aos clamores populares, como foi o caso da Rússia, no oriente europeu, cruzaram o século afogados em sangue revolucionário. As crises econômicas que anunciavam os anos 30, ao sabor do Charleston e dos novos tons que inflados discursos nacionalistas imprimiam aos ataques dirigidos à imobilidade estatal, em especial econômica e social, exortam adotar novas plumagens ao Cisne que valsava indiferente ao Danúbio.

Um novo papel era esperado do Leviatã, cujo horizonte teórico era destilado na primazia do bem-comum em detrimento do individualismo egocêntrico vigente na afirmação do status quo. $\mathrm{O}$ que fora revolucionário parecia remontar conservadorismos claudicantes. Emerge, em muitas estruturas e facetas, o estado intervencionista. E em muitos casos, como Hitler, Stalin, Mussolini, Franco e outros, com crescente radicalidade. ${ }^{14}$ Foi o caso de Vargas no Brasil, nas sístoles e diástoles de endurecimento no exercício do poder. É característico do Populismo que toma a América-Latina.

Com o tamanho crescente das estruturas burocráticas desse novo cisne que reina no lago, desenvolve-se toda a sofisticação do Direito Público, em especial com o nascimento do Direito Administrativo. Um corpo reestruturado mais condizente com as novas funções que chegam.

A Sociedade Industrial, que irrompe a Modernidade Tardia, não tem no Estado um papel de coadjuvante. Oposto às percepções tradicionais, bem representadas no

${ }^{14}$ Segundo Paulo Bonavides (2011, p.184): “O Estado Social representa efetivamente uma transformação superestrutural por que passou o antigo Estado liberal. Mas algo, no Ocidente, o distingue, desde suas bases, do Estado proletário, que o socialismo marxista intenta implementar: é que ele conserva sua adesão à ordem capitalista, princípio cardeal a que não renuncia. (...) A Alemanha nazista, a Itália fascista, a Espanha franquista, o Portugal salazarista foram 'Estados sociais'. Da mesma forma, Estado social foi a Inglaterra de Churchill e Attlee; os Estados Unidos, em parte, desde Roosevelt; a França, com a Quarta República, principalmente; e o Brasil, desde a Revolução de 1930." 
pensamento de Adam-Smith (2006), as visões de Keynes (1992), que impregnam o início do Século XX, solidificam a percepção da necessidade da mão invisível estatal na Economia.

As políticas do Neal Deal de Roosevelt dão claras mostras dessa viragem, qual a Lei Seca demonstra a emergente publicização do privado. Essa dinâmica mundial apresentava uma nova fotografia da estatalidade republicana em busca de reconcialiarse com certas camadas excluídas, com os mais diversos fins que se podem projetar no espaço entre as aldeias e o globo.

Significativo dessa distinta racionalidade estatal, bem mais próxima de Hegel do que de Kant, está em um Leviatã mais forte e consciente de seus poderes reais e simbólicos, bem como com uma renovada gama de instrumentos decorrentes dessas novas configurações onde Público e Privado, não raro, se indistinguem na plumagem do Cisne aos olhos de outrora.

Os exemplos saltam e refulgem em todos os horizontes, desde a tecnologia até o marketing desdobrando um novo modo de fazer leis, política e guerras. Tudo mudando e, paradoxalmente, se mantendo.

Na nova valsa do Leviatã, o Público irrompe no palco Privado. Os valores e discurso derivados da axiologia do bem-comum e da teleologia da isonomia imprimem novos tons à plumagem do Cisne e novas ondulações no espelho d'agua do lago da Sociedade Industrial, outrora expressivos dos matizes valorativos liberais de manutenção do status quo. Agora nacionalista, sindicalista e intervencionista.

As avenidas que se abriam do Público ao Privado eram asfaltadas pelos nascentes direitos fundamentais de segunda dimensão e a lei passa a corporificar o veículo da crescente intervenção publicizadora do Direito. A conhecida descodificação do Direito Civil é uma face dessa moeda, demonstrativa da presença dessa renovada estatalidade nos horizontes privados.

Onde antes os direitos fundamentais, reduzidos à primeira dimensão, eram um oceano que claramente dividia o mundo em dois continentes opostos, nessa nova quadra de direitos, derivados das demandas sociais que estribaram o surgimento do novo Leviatã, atraindo o Público para dentro do Privado, passam a servir de ponte, impulsionando o Estado a manter-se presente na vida social, familiar e econômica (antigos redutos burgueses).

O laissez faire anterior se fez substituir por uma crescente inflação legislativa. O Cisne começa a sanha legislativa intervencionista em seu nado ao longo da Modernidade Tardia, decapando capítulos, dispositivos e seções inteiras do Código Civil (reduto da autonomia privada), para darem lugar ao universo de estatutos especializados e setoriais que retratam o inchaço do gigante burocrático estatal, agora presente em todos os setores da vida civil. 
Leis de todos os tipos e gêneros se multiplicam. Lei de Usura, Condomínios e Incorporações, Menores, Locações Residenciais, Comerciais, CLT, Mulher Casada, Loteamentos, Representantes Comerciais, Mercado de Capitais, Registros, Cheque, Cambiais, Divórcio, Alimentos,... Lá começou e até hoje segue em sua incansável produção legislativa.

Esse direito setorial, característico da fase intervencionista, promoveu a Era dos Estatutos e uma profunda descodifição do Direito, coerente ao desprestígio prático dos exegetas e pandectistas de outrora. ${ }^{15}$ A nova complexidade jurídica, piramidificava o Direito para garantir seu discurso de aparente certeza e determinismo.

Qual Einstein ${ }^{16}$ rompera com Newton ${ }^{17}$, o relativismo ganha força nas Ciências Sociais Aplicadas revelando um novo mundo e um deslocamento de racionalidade, não obstante a permanência do paradigma anterior. A negativa da relatividade de Einstein à expansividade do Cosmos, corresponde à negativa da abertura do sistema jurídico pela Teoria Pura de Kelsen (1995).

E os valores, presentes no discurso jurídico qual a matéria escura no Universo, ignorados pela epistemologia determinista vigente, são apropriados pela esfera política em prejuízo da própria República que deveriam instrumentalizar. ${ }^{18}$

De Bauman (1998) a Arendt (2008), são inúmeros os estudos que dão conta sobre o período nefasto vivido pela humanidade a partir da Europa, cujas marcas levaram os noruegueses a indicar ao Nobel da Paz de 2012 sua entidade, nascida enegrecida

15 "Os conceitos pandectistas são estereótipos representacionais dos valores liberais burgueses, congelados na imagem codificada que se propõe a ser um sistema autônomo e invulnerável, com pretensão de validade eterna, tal qual era o ideário do liberalismo clássico, em larga medida retomado pelo reacionário compromisso dos neoliberais com o mercado. São fotografias das representações sociais arcaicas, uma vez que constituem arquétipos axiológicos, a serem compreendidos e desmistificados". (ARONNE, 2001, p. 33-4).

${ }^{16}$ Para Boaventura Santos (2010, p.24): “Einstein constitui o primeiro rombo no paradigma da ciência moderna, um rombo, aliás, mais importante do que o que Einstein foi subjectivamente capaz de admitir. Um dos pensamentos mais profundos de Einstein é o da relatividade da simultaneidade. Einstein distingue entre a simultaneidade de acontecimentos presentes no mesmo lugar e a simultaneidade de acontecimentos distantes (...) Esta teoria veio revolucionar as nossas concepções de espaço e tempo. Não havendo simultaneidade universal, o tempo e o espaço absolutos de Newton deixam de existir."

17 Segue o autor: "Segundo a mecânica newtoniana, o mundo da matéria é uma máquina cujas operações se podem determinar exatamente por meio de leis físicas e matemáticas, um mundo estático e eterno a flutuar num espaço vazio, um mundo que o racionalismo cartesiano torna cognoscível por via da sua decomposição nos elementos que o constituem. Esta ideia do mundo-máquina é de tal modo poderosa que se vai transformar na grande hipótese universal da época moderna, o mecanicismo." (SANTOS, 2010, p. 17).

${ }^{18}$ Segundo Ricardo Aronne (2006, p. 27): “As geniais teorias de laboratório, fruto do racionalismo cartesiano ainda presente e forte, operadas por Kelsen na primeira metade do único século que assistiu a duas guerras mundiais que arrasaram a Europa podem ser apontadas como o sinal de agonia de um dogmático positivismo determinista de matriz kantiana, que de muito já se revelara insuficiente para descrever a beleza e o horror do homem concreto." 
do carvão que blindava os interesses franceses e alemães e levaria ao Tratado de Mastrich e a Europa atual.

Portanto, o Cisne trajava a mais alva plumagem, ao valsar no Danúbio que pedia sua presença rente as demandas sociais que se agravavam com as crises do início do século XX e produziram as duas mais sangrentas guerras da humanidade (HOBSBAWM, 2012). Adentrou o Danúbio e valsou como o cisne mais negro que jamais valsou, tingindo o azul de rubi.

O lago sujo de sangue, onde o Direito lavara suas mãos... ${ }^{19} \mathrm{Na}$ sua assepsia aos valores promoveu a tirania em todos os setores da vida, sob o golpe do cajado do Leviatã. ${ }^{20}$ O mundo, aos poucos, começa a acordar do sonho moderno em que se aninhara, descobrindo que o amanhã pode ser pior, ordem nem sempre traz progresso e que tecnologia e ciência podem ser um pesadelo.

A ressaca paradigmática da racionalidade e das certezas denunciam a primavera da Modernidade Líquida (BAUMAN, 2001) que anunciaria a Pós-Modernidade ao fim da Guerra-Fria. ${ }^{21} \mathrm{E}$ o Cisne, indiferente às suas cores, segue seu nado... Segue a sua valsa...

\section{Cinguenta TONS DE AZUL PARA O DANÚbio}

Quando feito um recorte na historicidade que produziu o Leviatã Pós-Moderno, percebe-se um Estado que, mesmo se valendo do instrumental desenvolvido na Modernidade, tem uma presença muito distinta na Sociedade do que se via outrora.

Essa mudança, inaugurada desde suas bases funcionais até seus mecanismos de atuação, inevitavelmente termina por expressar-se nas respectivas instituições, seja na esfera do classicamente tratado como político ou jurídico.

19 “Schmitt (com o seu 'pensar por ordenamentos concretos') e Larenz (com os “conceitos gerais e concretos') não ofereceram ao nazismo teorias de Direito, nem mesmo a descrição de direitos vigentes, mas aquinhoaram o nazismo com um instrumento para modificar, completar e cancelar o Direito herdado, substituindo-o por meras regras totalitárias instrumentais para a ideologia nazista. (...) O Direito Nazista, assim, nascia da mais sombria realidade histórica, sem nenhum juízo crítico, ético ou moral sobre os fatos contemporâneos. A realidade era apenas a realidade do nazismo." (SCLIAR, 2012, p. 72).

${ }^{20}$ Para Barzotto (2007, p. 127): "Não podendo fundar o direito sobre concepções valorativas, nem sobre o poder, sem violar o valor segurança, o positivismo foi levado a propor um fundamento jurídico para o próprio direito. Isto significa que ele foi constrangido a construir aquilo que foi chamado, ao longo deste trabalho, um conceito 'autônomo'de direito. Autônomo em relação ao plano fático (eficácia) e valorativo (justiça)".

${ }^{21}$ Para Hobsbawm (2012, p.236): "O efeito da Guerra Fria foi mais impressionante na política internacional do continente europeu que em sua política interna. Provocou a criação da 'Comunidade Européia', com todos os seus problemas; uma forma de organização sem precedentes, ou seja, um arranjo permanente (ou pelo menos duradouro) para integrar as economias, e em certa medida os sistemas legais, de vários Estados-nação independentes." 
Mas, paradoxalmente coerente à valsa desse leviatã que cruza os salões da história, tal gama de mudanças decorre de um complexo e não linear conjunto de interações no escopo social, político e econômico das nações a partir do pós-guerra, em que os intercursos que vão do público ao privado parecem se destonalizar como um horizonte onde o mar veste as mesmas cores do firmamento. ${ }^{22}$

Seja nos matizes neoliberais, seja pela opcão social-democrática, abraçada pela Carta de 1988 no Brasil, é inconcebível quaisquer neutralidades no campo interventivo estatal, nos diversos setores da sociedade e da economia na contemporaneidade. As mais recentes crises mundiais (respectivamente Japão, México, EUA e Europa), demonstram claramente isso, ao expor a vulnerabilidade dos estados de fraca potencialidade interventiva.

Nenhum campo resulta descoberto da potencialidade projetiva estatal, por decorrência da abertura do Sistema Jurídico às demandas individuais (singulares ou homogêneas), aos diversos campos de postulação coletiva e, em especial, ao rico campo dos interesses difusos, de jovem emêrgencia.

Os cisnes se adaptam às turbulentas águas do contemporâneo Danúbio, cujas cores são tão indistintas (ante o pluralismo que agora o caracteriza) quanto a plumagem dos cisnes em seu balé, valsando até as margens sob influência das correntes decorrentes dos muitos cisnes no espelho d'água. ${ }^{23}$

Mas se as amarras que prendiam Ulisses ao mastro estão soltas, o que impede que a nau não seja atirada às rochas, pela sedução do canto das sereias? Quando Foucault (2006) propõe a polifônica concepção de biopoder, diversos sentidos podem ser retirados em prol de responder essa questão. Isso porque ela há de desafiar para além do simples plano normativo, para alcançar um recorte justificativo no plano do controle político do poder e sua legitimidade. ${ }^{24}$

${ }^{22}$ Conforme Ilya Prigogine (1996, p.57): "Se nosso mundo devesse ser compreendido através do modelo dos sistemas dinâmicos estáveis, não teria nada em comum com o mundo que nos cerca: seria um mundo estático e predizível, mas não estaríamos lá para formular as predições. No mundo que é o nosso, descobrimos em todos os níveis flutuações, instabilidades. Os sistemas estáveis que levam a certezas correspondem a idealizações, a aproximações."

${ }^{23}$ Segundo Ricardo Aronne (2006, p.52): “Os valores antecedem o conteúdo normativo principiológico ou regrativo trazendo o ideário axiológico do sistema, de modo vinculante. Eles integram as normas, porém não são normas jurídicas. Para análise, observa-se que a formação do sistema vigente se iniciou pela opção de seus valores de arrimo, no preâmbulo da Constituição, que positivou a solidariedade, o pluralismo, a justiça, a igualdade, a liberdade, entre outros, como valores supremos, na base do princípio estruturante, alimentando-o axiologicamente para dar-lhe sentido objetivo, de racionalidade intersubjetiva".

${ }^{24}$ Continua o autor: "Ao interprete e aplicador do Direito, decorre um compromisso na atividade hermenêutica, com o conjunto de valores que integram a opção axiológica da Constituição. A interpretação, tal qual a norma, pelo caráter axiológico, tem seus filtros de legitimidade. Atratores intersubjetivos do discurso." (ARONNE, 2010, p. 67). 
Se no primeiro salto histórico do Estado Moderno, no breve fosso da Modernidade Sólida e Tardia, chocou à sociedade perceber que Liberalismo não era sinônimo de Democracia, agora o pluralismo tonaliza uma bricolada plumagem ao Cisne. Percebe-se, então, com potencializada complexidade ao sistema, que Democracia não é o direito da maioria e sim o direito de todos. E isso muda o modo de jogar o jogo desde sua hermenêutica substancial. ${ }^{25}$

Afinal, que arma enganosa soube ser o plebiscito nas mãos da política nazista. Mesmo diante da planificada sociedade da Modernidade Tardia, o totalitarismo ${ }^{26}$ conseguiu se vestir de legitimidade formal e eviscerar aquilo que se passou "a creditar" como Direitos Humanos ${ }^{27}$ nas democracias ocidentais contemporâneas.

Talvez essas percepções possam fugir ao sentido dos olhares mais jovens, por não perceberem a revolução promovida por um real paradigma que introduz a noção de que "inventamos a nós mesmos". Que a existência precede a essência, na manchete filosófica vociferada por Sartre (2010).

As instituições, por mais tradicionais que sejam suas concepções, não conseguem caber ou compartimentar-se em um mundo de codificações, onde o político se desprenda do jurídico, econômico, social ou ambiental; onde é livre a opção sexual de vida; onde não existe uma fórmula sobre o afeto, não obstante passar ao centro das relações familiares; onde a dinâmica econômica é tão fluída que, apesar de demandar a presença do Estado em seu fluxo, não pode viver sob o tempo da cristalização legislativa das regras; onde interesses difusos, cujo debate é impassível de circunscrição, regem a discussão sobre as matas ciliares e sua recomposição, na clara representação da projeção do espectro público para os interesses da tradicional propriedade privada. ${ }^{28}$

Talvez onde resulte a maior perplexidade é que, mesmo tendo como pacífico os muitos exemplos colhidos como grãos de areia em uma praia de obviedades, certos setores do ensino e da literatura jurídica tradicional parecem completamente distantes dessa

${ }^{25}$ Para Juarez Freitas (1995, p. 40): “(...) Em tal linha, sempre em atenção a imprescindível e irrenunciável meta de um conceito harmônico com racionalidade intersubjetiva, entende-se mais apropriado que se conceitue o sistema jurídico como uma rede axiológica e hierarquizada de princípios gerais e tópicos, de normas e de valores jurídicos cuja função é a de, evitando ou superando antinomias, dar cumprimento aos princípios e objetivos fundamentais do Estado Democrático de Direito, assim como se encontram consubstanciados, expressa ou implicitamente, na Constituição."

${ }^{26}$ Conforme Wremyr Scliar (2012, p. 72): “As leis, elaboradas pelos juristas, assim como as sentenças, nada mais eram do que regras ditadas pelo partido, no interesse da classe dominante e do partido dominante, e eram apenas instrumento deste programa".

27 Ver Lyn Hunt (2009).

${ }^{28}$ De acordo com Maria Celina Bodin de Moraes (1992, p. 24): “Acolher a construção da unidade (hierarquicamente sistematizada) do ordenamento jurídico significa sustentar que seus princípios superiores, isto é, os valores propugnados pela Constituição, estão presentes em todos os recantos do tecido normativo, resultando, em consequência, inaceitável a rígida contraposição público-privado". 
realidade que ocupa a vida cotidiana e acompanha a aplicação e a reflexão contemporânea dos institutos jurídicos, desde os mais rudimentares aos mais sofisticados. ${ }^{29}$

Quer parecer que o ensino fundamental do Direito, em especial o Privado, parece petrificado como sob os olhos da Medusa. E adorado, por muitos, qual o boi Àpis. Não obstante, imersa na vida transitória da Sociedade de Hiperconsumo (LIPOVETSKY, 2012), os indivíduos paradoxalmente vivem uma Síndrome de Perseu. E no paradoxo dessa dobradura do real, emergem inúmeras dificuldades ao Direito Contemporâneo. Qual os aplausos para a Lei da Ficha Limpa, cujas entrelinhas importam em amputações políticas do cidadão, em face de vulnerabilidades derivadas de uma imanente imaturidade democrática.

\section{O CISNE E O LAGO}

O Estado segue estado e a Sociedade segue sociedade. Nada mudou ? Estado e Sociedade se reconheceriam, no espelho do tempo, por trás dos vincos e rugas de sua historicidade? Tudo mudou, com suficiente clareza para mostrar quão vãos são os esforços de esquadrinhar os albuns de família em busca das similitudes do netinho com seu idoso bisavô. Até a contingência parental se estriba sobre novos pilares, bem menos patrimoniais, diante do óleo essencial de existencialidade, promovida pela repersonalização do Direito.

Os institutos jurídicos, deixam de se perceber públicos ou privados, para expressarem uma nova racionalidade, passível de implicar quão público ou privado possam, respectivamente, se situar em concreto, seja nos fundamentos de uma ou outra dessas interconectadas e cambiantes frações de um todo, inexprimível nas articulações oitocentistas. $^{30}$

Sequer a imagem do Cérbero, como expressão dos tradicionais freios e contrapesos, engendrados mecanicamente por Montesquieu (1995), na projeção do Estado Tripartite, atravessa sem arranhões o tempo.

${ }^{29}$ Para Edgar Morin (2005, p.15): “A patologia moderna da mente está na hipersimplificação que não deixa ver a complexidade do real. A patologia da idéia está no idealismo, onde a idéia oculta a realidade que ela tem por missão traduzir e assumir como a única real. A doença da teoria está no doutrinarismo e no dogmatismo, que fecham a teoria nela mesma e a enrijecem. A patologia da razão é a racionalização que encerra o real num sistema de idéias coerente, mas parcial e unilateral, e que não sabe que uma parte do real é irracionalizável, nem que a racionalidade tem por missão dialogar com o irracionalizável."

${ }^{30}$ Para Edgar Morin (2005, p.14): “(...) o desafio da globalidade é também um desafio de complexidade. Existe complexidade, de fato, quando os componentes que constituem um todo (como o econômico, o político, o sociológico, o psicológico, o afetivo, o mitológico) são inseparáveis e existe um tecido interdependente, interativo e inter-retroativo entre as partes e o todo, o todo e as partes. Ora, os desenvolvimentos próprios de nosso século e de nossa era planetária nos confrontam, inevitavelmente e com mais e mais frequência, com os desafios da complexidade." 
Na contemporaneidade do Leviatã, diversas outras cabeças dotadas de institucionalidade e autonomia, emergem do corpo estatal. Ministério Público, em suas várias escalas, os tribunais de contas, CADE, BACEN, CNJ, as agências reguladores, as ONGs, e muitos outros exemplos a serem colhidos no jardim que ofereceu àquela primeira flor, colhida no ramalhete temático deste breve ensaio, cujo final se anuncia.

A plural plumagem do Cisne que valsa no Danúbio pós-moderno tem seus tons prismados na paleta dos direitos fundamentais, herança moderna que cotidianamente há de ser revisitada da mais sublime à mais rudimentar jurisprudência. Onde pode-se aferir que, das entranhas do Leviatã, uma Hidra de Lerna, cujas cabeças superam em muito a tríade de Cérbero, se lança ao lago, no papel nunca neutro, do Cisne Imperial.

\section{REFERENCIAS}

ARENDT, Hannah. Homens em Tempos Sombrios. São Paulo: Cia das Letras, 2008.

ARISTÓTELES. A Política. Rio de Janeiro: Martins Fontes, 2011.

ARONNE, Ricardo. Direito Civil-Constitucional e Teoria do Caos - Estudos Preliminares. Porto Alegre: Liv. do Advogado, 2006.

. Razão \& Caos no Discurso Jurídico e outros estudos de Direito Civil-Constitucional.

Porto Alegre: Liv do Advogado, 2010.

. Por uma nova hermenêutica dos direitos reais limitados - das raízes aos fundamentos contemporâneos. Rio de Janeiro: Renovar, 2001.

. A Favela e o Estado: Brevíssimo Ensaio entre a Maloca e a Àgora. IN: GRUNE, Carmela. (Org.). Direito na Cabeça e Samba no Pé. São Paulo: Saraiva, 2012, no prelo.

BAUMAN, Zigmunt. Modernidade e Holocausto. Rio de Janeiro: JZE, 1998.

. Modernidade e ambivalência. Rio de Janeiro: JZE, 1999.

. Modernidade líquida. Rio de Janeiro: JZE, 2001.

BARZOTTO, Luís Fernando. O Positivismo Jurídico Contemporâneo: Uma introdução a Kelsen, Ross e Hart. São Leopoldo: Unisinos, 1999.

BLAINEY, Geofrey. Uma Breve História do Mundo. São Paulo: Fundamento, 2008.

BOBBIO, Norberto. Teoria do ordenamento jurídico. Trad. Maria Celeste dos Santos. 6.ed. Brasília: Ed. UNB, 1995.

. O positivismo jurídico. Trad. Edson Bini. São Paulo: Ícone Ed., 1995.

BONAVIDES, Paulo. Do Estado Liberal ao Estado Social. São Paulo: Malheiros, 2011.

FACHINI NETO, Eugênio. Reflexões histórico-evolutivas sobre a constitucionalização do direito privado. In: Constituição, Direitos Fundamentais e Direito Privado. SARLET, Ingo (Org.). Porto Alegre: Livraria do Advogado, 2010.

FOUCAULT, Michel. Microfísica do poder. 22.ed. São Paulo: Cultrix, 2006.

FREITAS, Juarez. A Interpretação Sistemática do Direito. São Paulo: Malheiros, 1995.

FREUD, Sigmund. O Futuro de uma Ilusão, o Mal Estar na Civilização e Outros Trabalhos - v.XXI.

São Paulo: Imago, 2006. 
GILISSEN, John. Introdução histórica ao direito. 2.ed. Lisboa: Fund. Calouste Gulbenkian, 1995.

HOBBES, Thomas. Leviatã. São Paulo: Martin Claret, 2005.

HOBSBAWM, Eric. Era dos extremos: o breve século XX - 1914-1991. São Paulo: Cia. das Letras, 2012.

HUNT, Lyn. A Invenção dos Direitos Humanos. São Paulo: Cia. das Letras, 2009.

KANT, Imanuel. Fundamentação da metafísica dos costumes. São Paulo: Martin Claret, 2003.

. Crítica da razão pura. Lisboa: Calouste Gulbenkian, 1997.

KELSEN, Hans. A teoria pura do direito. Trad. João B. Machado. 4.ed. São Paulo: Martins Fontes, 1995.

KEYNES, J.M. Teoria geral do emprego, do juro e da moeda. São Paulo: Atlas, 1992.

LIPOVETSKY, Gilles. Os tempos Hipermodernos. São Paulo: Barcarolla, 2012.

LISSAGARAY, P. Olivier. História da Comuna de 1871. São Paulo: Editora Ensaio, 1991.

LÔBO, Paulo Luiz Netto. Constitucionalização do direito civil. Revista de Informação Legislativa.

Brasília: senado federal, n. 141, 1999, p. 99-109.

LOCKE, John. Segundo Tratado sobre o Governo Civil. São Paulo: Martin Claret, 2005.

MONTESQUIEU, Secondant du. O Espírito das Leis. Brasília: Ed. UNB, 1995.

MORAES, Maria Celina Bodin de. A Caminho de um Direito Civil Constitucional. Revista de Direito Civil. São Paulo: RT, n. 65, 1992.

MORIN, Edgar. A Cabeça Bem-Feita: Repensar a Reforma, Reformar o Pensamento. Rio de Janeiro: Bertrand Brasil, 2005.

. Cultura e Barbárie Europeias. Lisboa: Instituto Piaget, 2005.

PRIGOGINE, Ilya. O fim das certezas: tempo, caos e as leis da natureza. São Paulo: UNESP, 1996.

RAMOS, Carmem Lucia Silveira. A Constitucionalização do Direito Privado e a Sociedade sem Fronteiras. IN: FACHIN, Luiz Edson. (Org.). Repensando os Fundamentos do Direito Civil Brasileiro Contemporâneo. Rio de Janeiro: Renovar, 1998.

ROUSSEAU, Jean-Jacques. O Contrato Social. São Paulo: Martin Claret, 2005.

SALDANHA, Nelson. O jardim e a praça: ensaio sobre o lado privado e o lado público da vida social e histórica. Porto Alegre: SAFE, 1986.

SANTOS, Boaventura de Souza. Um discurso sobre as ciências. São Paulo: Cortez, 2010.

. Pela mão de Alice: o social e o político na pós-modernidade. 8.ed. São Paulo: Cortez, 2001.

SARTRE, Jean-Paul. O ser e o nada. Petrópolis: Vozes, 2010.

. O existencialismo é um humanismo. São Paulo: Abril Cultural, 1984.

SCLIAR, Wremyr. Direito Nazista: Faltaram dois réus em Nuremberg. In: Revista História Catarina. Lages: Editora Leão Baio, Ano VII, Número 47- 2012.

SMITH, Adam. A Riqueza das Nações. São Paulo: Momento Atual, 2003.

SZTOMPKA, Piotr. A Sociologia da Mudança Social. Rio de Janeiro: Civilização Brasileira, 1998. 